Article

\title{
Three Bizarre Presidential-Election Scenarios: The Perils of Simplism
}

\author{
Richard F. Potthoff (D) \\ Department of Political Science and Social Science Research Institute, Duke University, Box 90420, \\ Durham, NC 27708, USA; potthoff@duke.edu
}

Received: 28 March 2019; Accepted: 19 April 2019; Published: 29 April 2019

check for updates

\begin{abstract}
The 1968, 2000, and (future) 2024 U.S. presidential elections provide settings for deliberately provocative, offbeat scenarios that might have happened or could happen. Throughout, the Electoral College and plurality voting both receive blame. Scenario 1 exposes a quirk previously unnoticed: Under (albeit special) conditions, certain 1968 Humphrey voters could have made Humphrey rather than Nixon the election victor had they voted strategically for Wallace instead of Humphrey. In Scenario 2, overlooked nonidentifiability of undervotes would have plagued the 2000 Florida recount had the U.S. Supreme Court not halted it, thus raising questions about the foresightfulness of almost everyone involved; but, in addition, Gore missed an opportunity that, through use of proper statistical sampling, could have propelled him to victory. In Scenario 3, National Popular Vote Interstate Compact supporters fail to foresee that even one state, by changing its method for presidential voting, can wreck this innovative and widely promoted compact.
\end{abstract}

Keywords: 2000 Florida recount; Electoral College; National Popular Vote Interstate Compact; plurality voting; statistical sampling

\section{Introduction}

This paper describes three possible scenarios of United States presidential elections, two past and one future, that serve as vehicles to provoke careful thought about certain aspects of these elections and to emphasize the need to steer clear of simplistic conclusions. In one way or another, all three involve defects of the workings of the Electoral College. But the Electoral College is not the sole villain. All three scenarios also reflect troubles, not easy to dodge, that stem from the competition from candidates beyond those of the two major parties. Thus, simplistic reforms that are aimed at the Electoral College alone, without recognition of the complexities that are inherent in multicandidate elections, could be limited in the benefit that they provide.

Elsewhere, one can find more than adequate discussion of the Electoral College, including strong arguments for it (e.g., Hardaway 1994; Best 1996; Ross 2012) and against it (e.g., Peirce and Longley 1981; Longley and Peirce 1999; Edwards 2011; Koza et al. 2013). More in the middle of the road are the writings of (Sabato (2007, pp. 134-52), “The Electoral College: Mend It, Don't End It") and Miller (2012). Arguments opposing and supporting elimination of the Electoral College generally involve such issues as federalism (powers possessed by states, divergence among states as to rules for voting and elections); perceived fairness (electoral-vote winner differing from popular-vote winner, power of large versus small states, winner-take-all rule for electoral votes of states); and power of, or effects on, different groups or entities (urban versus rural areas, swing states, minorities, the two-party system). Typically unquestioned, though, is the suitableness of plurality voting, the entrenchment of which in U.S. electoral systems is broadly taken for granted.

Although the Electoral College is an important disruptive factor in our scenarios, plurality (first-past-the-post) voting systems also play a major aggravating role. They are viewed in conjunction 
with the concept of the Condorcet candidate (one who could beat each competitor one-on-one), often felt to be a basic element in relation to multicandidate single-winner elections. Most authors (see, e.g., Dasgupta and Maskin 2004; Gehrlein 2006, p. 29; Merrill 1988, p. 6; Regenwetter et al. 2006, p. 111) agree on the desirability of an election winner being a Condorcet candidate (if one exists). A dissent, though, comes from Saari (1995), who demurs especially because of problems that arise with the nonexistence of a Condorcet candidate.

Among voting-system gurus, one finds much more agreement about the deficiencies and inferiority of plurality voting than about what alternative system is the best one to replace it. Besides many of the references just cited, see e.g., especially Dummett (1997); Tideman (2006) and Poundstone (2008) for coverage of plurality voting and various alternatives. Some of those other systems play a role in Scenario 3 below.

Our Scenario 1 concerns the 1968 election, in which Richard Nixon (Republican), Hubert Humphrey (Democrat), and George Wallace (American Independent Party) were the leading contenders. Though not the first fictional chronicle or might-have-been analysis of that election, it has an entirely different angle from its predecessors. Some Humphrey voters in a few states are able to bring about the election of a Democratic president by voting for Wallace instead of Humphrey (with all other votes staying the same). The grotesque strategic voting that produces this result, attainable through several alternative paths, exploits not only the weaknesses of the Electoral College but also the vagaries of finding a winner in a multicandidate election.

Under Scenario 2, which pertains to the 2000 election where George W. Bush (Republican) faced Albert Gore (Democrat), the United States Supreme Court does not, after all, block the recount of the Florida undervote ballots (ballots with no vote detected) that the Florida Supreme Court had ordered. But then, rearing its ugly head is a serious flaw that should have been fully recognized beforehand but was not: The sets of undervote ballots that were simplistically presumed to be recountable are unidentifiable and thus, in effect, nonexistent. Chaos ensues. Typical claims arise that the entire Florida debacle would have been avoided had there been no Electoral College, because a small number of votes would not have played a critical role. But, as in Scenario 1, the diagnosis is not so straightforward, because a multicandidate race with a plurality voting system can create turmoil in any case.

Blossoming in the years after the 2000 U.S. presidential election produced an actual (electoral-vote) winner different from the plurality winner, the National Popular Vote Interstate Compact is an agreement that obligates each member state to cast all of its electoral votes for the presidential candidate who is the nationwide plurality winner, if enough states join the compact so that the total of their electoral votes exceeds half (currently 269) of the national total. Under Scenario 3, states with sufficient electoral votes do join by early 2024, completing a process that began with Maryland in 2007. But then a motley crew of political adventurers with assorted motivations travels to the capitals of four sparsely populated states, enticing their legislators and governors to scrap plurality voting and switch to other voting systems to pick the candidate who will win their 2024 electoral votes. Alas, blind faith that plurality voting is inextirpable has led to naive trust that the ingenious compact to elude the Electoral College cannot be torpedoed.

For our scenarios, or at least some of their elements, one might question how realistic they could be. The intent of this paper, however, is to be provocative: to use various ramifications of the three diverse scenarios as means for challenging conventional thinking and beliefs about different matters concerning presidential elections.

\section{Scenario 1: 1968}

Candidates Nixon, Humphrey, and Wallace, respectively, won 32, 14, and 5 of the 50 states plus District of Columbia in the 1968 presidential election, amassing 301, 191, and 46 electoral votes. Nixon would have had 302 electoral votes and Wallace 45, rather than 301 and 46, had not a renegade North Carolina elector voted for Wallace instead of Nixon (who had carried the state). In 17 of Nixon's 32 states, he received less than half the total vote, and less than Humphrey plus Wallace together. 
In any of those 17 states, the Humphrey voters hypothetically could have swung the state to Wallace if enough of them had voted for Wallace rather than Humphrey. California, whose 40 electoral votes went to Nixon when he obtained $47.8 \%$ of the popular (plurality) vote versus $44.7 \%$ for Humphrey and $6.7 \%$ for Wallace, is an extreme case. If $92 \%$ of Humphrey voters had instead voted for Wallace and all else was unchanged, then Nixon would have lost California to Wallace, Nixon's electoral-vote total would have dropped below the 270 needed for a majority in the Electoral College, and (upon action by Congress) a Democratic president could have been the outcome of the ensuing bedlam. But it hardly seems likely that $92 \%$ of California Humphrey voters could have been persuaded to engage in such a zany form of strategic voting.

Nonetheless, it is instructive to examine this type of manipulative voting in more detail, if for no other reason than to highlight the surprising perversity that strategic voting may potentially entail. Although the California manipulation would require $92 \%$ of the Humphrey voters, the needed percentage was lower in some of the other 16 states that Nixon won with below half the total vote. In particular, consider four of those states: Florida, where 39\% of the Humphrey voters could have switched the state from Nixon to Wallace by voting instead for Wallace; North Carolina, needing 28\%; South Carolina, 20\%; and Tennessee, 14\%. See the line labeled (E) in the top part of Table 1, which shows the calculations for these percentages as well as the electoral votes for each state.

Table 1. Data for four states (1968 election, Scenario 1).

\begin{tabular}{|c|c|c|c|c|}
\hline & Florida & North Carolina & South Carolina & Tennessee \\
\hline Votes for Nixon & 886,804 & 627,192 & 254,062 & 472,592 \\
\hline$\%$ for Nixon, (A) & $40.5 \%$ & $39.5 \%$ & $38.1 \%$ & $37.8 \%$ \\
\hline Votes for Humphrey & 676,794 & 464,113 & 197,486 & 351,233 \\
\hline \% for Humphrey, (B) & $30.9 \%$ & $29.2 \%$ & $29.6 \%$ & $28.1 \%$ \\
\hline Votes for Wallace & 624,207 & 496,188 & 215,430 & 424,792 \\
\hline \% for Wallace, (C) & $28.5 \%$ & $31.3 \%$ & $32.3 \%$ & $34.0 \%$ \\
\hline Nixon margin over Wallace, $(\mathrm{D})=(\mathrm{A})-(\mathrm{C})$ & $12.0 \%$ & $8.3 \%$ & $5.8 \%$ & $3.8 \%$ \\
\hline $\begin{array}{l}\% \text { of Humphrey votes needed to switch to Wallace to } \\
\text { defeat Nixon, }(E)=(D) /(B)\end{array}$ & $38.8 \%$ & $28.2 \%$ & $19.6 \%$ & $13.6 \%$ \\
\hline Electoral votes & 14 & 13 & 8 & 11 \\
\hline Total population age $21+, 4 / 1 / 70,{ }^{a}(\mathrm{~F})$ & $4,357,024$ & $3,003,766$ & $1,467,299$ & $2,378,734$ \\
\hline Black population age $21+, 4 / 1 / 70$, a $(\mathrm{G})$ & 525,299 & 566,808 & 376,272 & 321,961 \\
\hline Age $21+, \%$ black, $4 / 1 / 70,(\mathrm{H})=(\mathrm{G}) /(\mathrm{F})$ & $12.1 \%$ & $18.9 \%$ & $25.6 \%$ & $13.5 \%$ \\
\hline $\begin{array}{l}\text { Estimated votes cast by blacks, as a } \% \text { of all votes, }(\mathrm{I})= \\
51.6 \% \times(\mathrm{H}) /\{51.6 \% \times(\mathrm{H})+61.8 \% \times[100 \%-(\mathrm{H})]\}\end{array}$ & $10.3 \%$ & $16.3 \%$ & $22.4 \%$ & $11.6 \%$ \\
\hline $\begin{array}{l}\text { Estimated Humphrey votes cast by blacks, as a } \% \text { of all } \\
\text { votes, }(\mathrm{J})=92 \% \times(\mathrm{I})\end{array}$ & $9.5 \%$ & $15.0 \%$ & $20.6 \%$ & $10.6 \%$ \\
\hline $\begin{array}{l}\text { Estimated Humphrey votes cast by blacks, as a \% of all } \\
\text { Humphrey votes, }(\mathrm{K})=(\mathrm{J}) /(\mathrm{B})\end{array}$ & $30.6 \%$ & $51.2 \%$ & $69.5 \%$ & $37.8 \%$ \\
\hline
\end{tabular}

a From U.S. Bureau of the Census (1973).

Had Nixon thus lost to Wallace in those four states by virtue of enough Humphrey voters voting for Wallace, the electoral votes for Nixon would have been reduced to an inadequate 256 (302 minus 46, or 301 minus 45). If Florida had stayed with Nixon but the other three states had gone to Wallace, then Nixon would have had exactly the minimum 270 but with the vulnerability that the defection of a single one of his electors would have undone the victory.

If Nixon did not receive a majority of the 538 electoral votes, a Democratic president could have come about in different ways. Provided that there were no post-election switches of Wallace electors to Nixon (or Humphrey), as a result of a deal or otherwise, there would have been a contingent election for president in the U.S. House among the three candidates. In any such contingent election (e.g., Anonymous 1968; Peirce and Longley 1981; Glennon 1992; Hardaway 1994; Longley and Peirce 1999; Edwards 2011), each state has one vote; it loses its vote if a majority of its voting House members does not agree on one candidate; a candidate must receive the votes of at least 26 of the 50 states to win; and no candidate is elected if none is supported by 26 states. 
The 91st House of Representatives, elected in November 1968, had 26 states with a majority of Democrats, 19 controlled by Republicans, and 5 tied. Thus, Humphrey would have become president had he prevailed in all 26 states held by House Democrats.

But not all 26 of those states would necessarily have backed Humphrey in a contingent election in the House. Peirce and Longley (1981, p. 79) indicate that at most 24 would have done so (with Nixon also failing to get 26). They note that some Democratic House members made pre-election pledges that, if the election went to the House, they would vote for the candidate who won their district even if it was not Humphrey. Another possibility was that Democratic House members in states carried by Wallace might vote for Wallace rather than Humphrey. (In the strange scenario portrayed here, though, any tendency of such House Democrats to defect from Humphrey might be tempered by knowledge that some Wallace votes came from Humphrey supporters.)

Had the House been deadlocked, and for as long as it was deadlocked, the presidency would go to the new vice president, who (assuming no candidate had a majority of electoral votes for vice president) would be chosen by the Senate. It would choose between the two contenders with the most electoral votes, Spiro Agnew (Republican) and Edmund Muskie (Democrat). Because the 91st Senate elected in 1968 had 57 Democrats and 43 Republicans, Muskie would be the expected winner. Thus, the presidency would be held by a Democrat, and would remain so at least as long as the House deadlock continued.

Up to this point, it has been assumed that the new (91st) House and Senate rather than the old, lame-duck (90th) ones would be making the decisions. But the assignment of responsibility to the new Congress rather than the old is done not Constitutionally but by law, and thus could have been transferred in late 1968 by the 90th Congress to itself ( Anonymous 1968, p. 1819; Venetoulis 1968, p. 149). In fact, it was rumored that this could have actually happened had there been a deadlock after the 1968 election (Peirce and Longley 1981, p. 316). Moreover, unlike other authors, Hardaway (1994, pp. 60-61) contends that the old Congress rather than the new one is to resolve a deadlock even in the absence of a change in the law. In any event, the 90th House had 29 states controlled by Democrats, 18 by Republicans, and 3 tied (versus 26, 19, and 5 in the 91st), and thus would have been more likely to elect Humphrey. The 90th Senate had 62 Democrats and 38 Republicans (versus 57 and 43 in the 91st).

Some diagnoses of the 1968 election (e.g., Peirce and Longley 1981, p. 77) have examined how close it came to ending in a stalemate in the Electoral College and how few votes would have had to shift to produce one. More expansively, though, at least three authors (Baker 1968; Venetoulis 1968, pp. 154-72; Markham 1970) have penned intriguing imaginary accounts of that election. [It may also be noted that Longley and Peirce $(1999$, chp. 1) wrote a fantasy narrative of the 2000 presidential election.] As fanciful as the 1968 scenario depicted herein may be, the three 1968 fictional chronicles written earlier seem to be still more so.

For several reasons, one can question how realistic Scenario 1 could be. The most obvious point concerns the feasibility of implementing the voting strategy under which some Humphrey voters vote for Wallace in order to try to elect Humphrey (or Muskie). Many voters would not understand such manipulation and/or would find it repugnant, and thus would be hard to persuade to use it. The strategy would require considerable coordination. Moreover, its success would depend somewhat on accurately assessing the percentage breakdown among the three candidates in individual states so as to judge which states to target. Thus, although the four states in Table 1 do happen to provide fertile grounds for the strategy, it would be badly counterproductive in Texas (where Humphrey himself barely edged Nixon) and would unnecessarily waste resources in Arkansas (where Wallace won anyway, though not overwhelmingly).

In addition, the strategy would be hard to keep secret and would probably become generally known. It could then be thwarted if, in the four states, some Wallace voters whose second choice was Nixon decided to forgo voting for Wallace and instead cast sophisticated votes for Nixon. In fact, among Wallace voters in 1968, Nixon was heavily favored as a second choice over Humphrey (Kiewiet 1979). 
A post-election roadblock to the strategy of Scenario 1 could have arisen upon the outcome of no majority in the Electoral College. Wallace could have prompted his electors to vote for Nixon, with or without a deal, thereby electing Nixon (see, e.g., Peirce and Longley 1981, p. 75). Thus, the strategy could have been derailed after the election even if, in the election itself, it worked as designed.

Despite these factors that make Scenario 1 far-fetched, the very fact that such a scenario is conceivable is a testament to a severe defect in the voting system. Voters should not even have to consider tortuous voting strategies like those that the scenario entails.

One feature of Scenario 1 makes it even more disconcerting. In the four states in Table 1, black voters were a high percentage of the Humphrey voters, from whom the switchers to Wallace would be drawn. In those states, the respective percentages of black Humphrey voters to all Humphrey voters are estimated to be $31,51,69$, and $38 \%$ [see line $(\mathrm{K})$ of the table]. In three of them (all but Florida), these percentages far exceed the percentages $[39,28,20$, and $14 \%$ from line (E)] of all Humphrey voters needed to switch to Wallace to defeat Nixon. Thus, ironically and disturbingly, that opens up the eerie possibility that a bloc of black voters by themselves could have sunk Nixon in those three states (and thereby enhanced the chances of a Democratic president) by voting for a candidate who was anathema to them. ${ }^{1}$

Although it is true that the most outlandish aspects of Scenario 1 would be avoided by abolishing the Electoral College and changing to a system where the candidate with the most nationwide popular votes wins the presidency, the familiar problems with plurality voting would still be inescapable. In 1968, voters whose first choice was Wallace would still face the irksome dilemma of whether to vote for him (and "waste their vote," as some would say) or vote for their second choice. Interestingly, Nixon's narrow nationwide popular-vote margin over Humphrey, 43.4 to $42.7 \%$, belied the fact that Nixon was easily the Condorcet candidate: He apparently would have beaten Humphrey by about 54 to $46 \%$ or better in a two-way race, and would have handily topped Wallace head-to-head (see Kiewiet 1979; Abramson et al. 1995). If one accepts the concept that a Condorcet candidate ought to win an election, then there was an appreciable chance that the "wrong" winner (by that standard) would emerge in 1968, under either the existing system or a straight plurality system. Thus, under either system, the shifting of a tiny sliver of votes from Nixon to Humphrey or Wallace could have prevented the election of Nixon but would have left unaltered the status of Nixon as the clear-cut Condorcet winner. Under either system, of course, Wallace voters whose second choice was Nixon could have prevented the defeat of the Condorcet candidate, Nixon, by voting for him instead of Wallace (a similar point was made above in discussion of obstacles to Scenario 1). But voters should be able to mark their ballots without having to be concerned about complex tactical decisions.

Strategic voting has attracted abundant attention (and is not deemed undesirable in all cases). It does frequently occur (e.g., Hillygus and Treul 2014, and references therein). But one would be hard-pressed to find or concoct a strategic-voting scheme whose unsettling nature would rival that of Scenario 1.

1 Although the calculation routine for line $(\mathrm{K})$ involves some approximations, they all appear to have no more than minor impact. The derivation, for each state, of the percentage of voting-age population that is black [lines (F)-(H)] uses data from the 1970 decennial census (rather than November 1968). The conversion of those percentages to percentages of total votes cast by blacks [line (I)] uses 1968 voting-rate data that are based on the civilian noninstitutional voting-age population [not total voting-age population as for lines $(\mathrm{F})-(\mathrm{H})]$ and are for an entire Census region, the South (rather than for the individual states). These reported voting rates common to the South (U.S. Bureau of the Census 1969) are 3,094,000/5,991,000=51.6\% for blacks and $(20,994,000-3,094,000) /(34,941,000-5,991,000)=61.8 \%$ for non-blacks [used in the formula for line (I)]. Although the 51.6 and $61.8 \%$ rates over-estimate the true voting rates, there is no distortion to the calculation of line (I) so long as the degree of over-reporting is the same for both groups. For obtaining line $(\mathrm{J})$ of the table, the proportion of black voters who voted for Humphrey is taken to be $92 \%$, a value given by Axelrod (1972, Table 1) for nonwhite (rather than black) voters nationwide (he gave no breakdown by state or region). The $92 \%$ proportion is in between a 1968 pre-election polling figure (nonwhite, nationwide) of $85 \%$ (Gallup, Inc. 2015) and a value (black, nationwide) of 97\% from Converse et al. (Converse et al. 1969, p. 1085). 


\section{Scenario 2: 2000}

Although one may question the plausibility of Scenario 1, Scenario 2 is, unfortunately, fully realistic. After the 2000 presidential election, all events in Florida unfold, under Scenario 2, just as they actually did up until the period between December 9, 2000, when the U.S. Supreme Court ended the recount of undervote ballots that had been ordered (for most of the state) by the Florida Supreme Court, and December 12, when it rendered its final decision.

At this point, the scenario veers. Instead of blocking that recount, the U.S. Supreme Court allows a recount, of undervotes only, but for any such recount requires that all undervote ballots in all 67 counties are to be isolated and then recounted using uniform statewide standards to be specified by state authorities. This transpires virtually in line with the tenable pattern portrayed by Kaplan (2001, chp. 10), wherein Justice Anthony Kennedy switches sides to join the four justices who had opposed the stay that stopped the recount. Finishing the recount by December 12-the "safe harbor" (Kaplan 2001, p. 142) deadline date that affords some protections from challenges, based on the Electoral Count Act of 1887-is not deemed imperative.

The new recount begins. The required uniform standards are promulgated fairly quickly. (It is assumed, perhaps naively, that they are unambiguous. Their exact nature is irrelevant for purposes of Scenario 2, except they specify that a chad attached at only one or two corners on a punched-card ballot is deemed equivalent to a fully-punched chad.) Because of the new standards, all 67 counties have to start from square one in recounting all undervote ballots, those with no presidential vote detected. In each of the 67 jurisdictions, lawyers and other observers aiming to protect both Bush's and Gore's interests, reporters from television and other media, and hordes of rabid partisans from both sides all appear, striving to keep a close watch on the proceedings. Each and any vote could be critical.

A plethora of glitches, not unforeseeable but virtually unforeseen, come to light as the separation and recounting of the undervoted ballots unfurls. Uproars arise. It suffices here to relate the starting chapters of the stories of three of the myriad precincts with troubled recounts. These three all used punched-card ballots, which generally had more problems than mark-sense (optical-scan) ballots.

The recount for the Alligator Alley precinct draws early attention and commotion. Previous (November 8) and current ballot tallies for that precinct appear in Table 2. The precinct has 555 ballots. Before, the precinct had the overvotes (18) and undervotes (12) enumerated separately, but with no further details about those 30 uncounted ballots. (Overvote ballots are those with more than one presidential vote detected and thus do not count.) The instructions for the new tally say to isolate the undervotes and then examine them. Accordingly, 9 ballots now identified as undervotes are found, and nothing is known about the remaining 546 (which include overvotes as well as valid presidential votes). Of the 9 ballots, 5 have intact chads for all presidential candidates and therefore qualify as true abstentions. But the other 4 are identified as undervotes merely because they each have a chad for one candidate that is attached at just one or two corners but was misinterpreted by the tabulating machine as intact. These 4 ballots convert from undervotes to valid votes, 1 from a Bush chad and 3 from Gore chads. 
Table 2. Vote tallies for the Alligator Alley precinct (2000 election, Scenario 2).

\begin{tabular}{|c|c|c|c|c|}
\hline Old & & Now & & \\
\hline George W. Bush & 416 & \multirow{3}{*}{ All except undervotes } & \lceil & \multirow{4}{*}{546} \\
\hline Al Gore & 104 & & i & \\
\hline Ralph Nader & 5 & & i & \\
\hline Overvotes & 18 & & L & \\
\hline \multirow{3}{*}{ Undervotes } & \lceil & Undervotes $\rightarrow$ Bush & & 1 \\
\hline & 12 & Undervotes $\rightarrow$ Gore & & 3 \\
\hline & L & Undervotes $\rightarrow$ no one & & 5 \\
\hline Total & 555 & Total & & 555 \\
\hline
\end{tabular}

But quickly a dilemma comes to light. The number of undervoted ballots found by the machine was previously 12 but is now only 9. (Certain secondary snags are now ignored but are briefly covered later.) The ballots seem to include $416+1=417$ votes for Bush, $104+3=107$ for Gore, and 5 for Nader (Green Party), plus 18 overvotes and 5 (true) undervotes. The total, though, is only 552, whereas 555 ballots exist! It appears that 3 ballots tallied as undervotes in the first run have now been classified as valid votes (explainable, e.g., by partially attached chads being closed in the first run but opening up or falling out in the second). But for which candidate did each of those 3 ballots register? One can find no way to answer this, given that the recount instructions restrict the process to just isolating the undervoted ballots and then inspecting them.

Pandemonium breaks loose as the pesky results for Alligator Alley sink in. The Bush observers on the scene claim that the 3 strayed ballots should be allocated 3-to- 0 to Bush because Bush heavily won the precinct. The Gore side counters that they should go 3-to-0 for Gore because his high share of the recovered undervote ballots ( 3 votes out of 4 ) suggests that Gore voters are more prone to punch out a chad incompletely. Various television personalities are not bashful about chiming in. One pundit, Quincy Quant, advocates 2.25 votes for Gore and 0.75 for Bush, based on the same proportions (75\% and $25 \%$ ) as in the recovered undervote ballots. His colleague, Sarah Savant, says she would agree with him except that she does not like fractional votes and thinks they may not be legally allowable, so she rounds and proposes 2 for Gore and 1 for Bush. Mortimer Mittelpunkt suggests 1.5 each for Bush and Gore, but upon realizing that the effect would be essentially the same as ignoring the 3 ballots entirely, switches to favoring 0 for each; he concludes that it is simplest, and perhaps most defensible legally, to report just the 552 votes. Decimo Doyen comes up with 2.4 for Bush and 0.6 for Gore, based on the same proportional split as in the precinct totals of 416 and 104. Sally Sage argues for rounding these values to 2 for Bush and 1 for Gore.

Meanwhile, results for the Crocodile Corridor precinct materialize as in Table 3. The current tally for Crocodile Corridor, unlike that for Alligator Alley, shows more (not fewer) undervotes than earlier, 11 versus 8 . Of the 11 current ones, 4 have all presidential chads intact and thus classify properly as undervotes. The remaining 7 each have one chad attached on only one or two corners with 5 Bush chads and 2 Gore chads, whence the 7 ballots all represent valid votes. So there now appear to be $244+5=249$ votes for Bush, $732+2=734$ for Gore, and 1 for Buchanan (Reform Party), plus 14 overvotes and 4 (true) undervotes, thereby totaling 1002. But there are just 999 ballots. Of the 7 current ballots that convert from undervotes to valid votes, apparently 3 were tallied previously as valid votes (presumably with their partially attached chads open on the first machine run but closed on the second). But which 3 have now been double counted? 
Table 3. Vote tallies for the Crocodile Corridor precinct (2000 election, Scenario 2).

\begin{tabular}{|c|c|c|c|c|}
\hline Old & & Now & & \\
\hline George W. Bush & 244 & \multirow{3}{*}{ All except undervotes } & 「 & \\
\hline Al Gore & 732 & & I & \\
\hline Pat Buchanan & 1 & & | & 988 \\
\hline Overvotes & 14 & & $\mathrm{~L}$ & \\
\hline & $\Gamma$ & Undervotes $\rightarrow$ Bush & & 5 \\
\hline Undervotes & | & Undervotes $\rightarrow$ Gore & & 2 \\
\hline & L & Undervotes $\rightarrow$ no one & & 4 \\
\hline Total & 999 & Total & & 999 \\
\hline
\end{tabular}

Amidst great turmoil at the counting site, the Gore side claims that all 3 excess votes should be deducted from Bush's total, because Bush has most of the converted undervotes (5 out of 7 ). Noting that the full precinct vote went heavily for Gore, the Bush side wants to deduct all 3 from Gore's total, but reluctantly changes its mind and favors a reduction of 1 for Bush and 2 for Gore upon realizing that Gore has only 2 converted undervotes available to subtract. Quincy Quant calculates a reduction of $2 \frac{1}{7}$ for Bush and $\frac{6}{7}$ for Gore based on the 5-to-2 ratio of the converted undervotes. Sarah Savant rounds that to 2 and 1 . Conceding that making no adjustments for this precinct would be untenable because the 1002 total cannot result from only 999 ballots, Mortimer Mittelpunkt recommends paring 1.5 from Bush and 1.5 from Gore. Failing to notice that Gore has just 2 votes available to deduct, Decimo Doyen figures decreases of 0.75 for Bush and 2.25 for Gore by using the same proportions as in the precinct totals of 244 and 732. Sally Sage rounds these values to 1 and 2.

The Panther Parkway precinct continues the unending drama. It is in a county whose earlier run did not enumerate overvotes and undervotes separately but rather found only a combined total, a situation apparently seen in a minority of counties (see 2000; New York Times Co. 2001, p. 285; Kalt 2001, Appendix 5). Then, because pulling out the undervote ballots is not straightforward for this county, the current run, carried out in disregard of instructions, first segregates all the no-votes (both overvotes and undervotes) for a precinct, and thereupon isolates the undervotes from those no-votes. The number of overvotes is thus known after all. (Some counties did seem to face problems in culling out the undervotes; see Pleasants 2004, pp. 22, 280-81.) Table 4 shows how the Panther Parkway tallies turn out. The number of overvotes plus undervotes combined, 32 in the old run, is $36(=19+1+7+9)$ in the current run. Of the 17 current undervote ballots, 9 have all chads intact, but the others have a chad with just one or two corners attached and are thus recoverable as valid votes, with 1 for Bush and 7 for Gore. Current revised totals seem to be $999+1=1000$ for Bush, $666+7=673$ for Gore, 33 for Nader, and 2 for Browne (Libertarian Party), plus 19 overvotes and 9 (true) undervotes. The total is 1736, or 4 more than the number of ballots. It is presumed that 19 detected overvotes existed in the old just as in the current run, that the old run thus found only 13 $(=32-19)$ undervotes, and that $4(=17-13)$ ballots counted as valid votes in the old run registered as undervotes in the current run as a result of their chads changing from open to closed. Which 4 ballots are double counted? 
Table 4. Vote tallies for the Panther Parkway precinct (2000 election, Scenario 2).

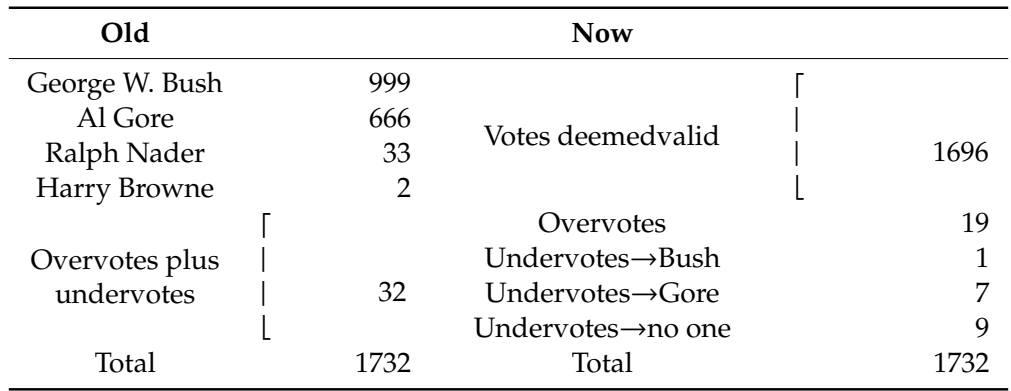

The Bush crew wants to remove all 4 from Gore because Gore has the bulk of the converted undervotes. The Gore forces would like to remove all 4 from Bush because Bush carried the precinct, but discover that that remedy will not work because only 1 converted undervote for Bush is available for removal and thus at least 3 must come from Gore. They then forge creative reasoning and argue that if the second run had adhered strictly to instructions and just isolated the undervotes, then the number of overvotes (19) would never have become known and would have been presumed to be 15 (=32 - $1-7-9)$, whence all 8 converted undervotes (1 Bush, 7 Gore) would have been, and should be, retained. Predictably, the Bush side is furious.

Based on the 1-to-7 ratio, Quincy Quant figures a reduction of 0.5 votes for Bush and 3.5 for Gore. Sarah Savant does not know whether to round that to 0 and 4 or to 1 and 3 (it makes a 2-vote difference in the Gore-vs.-Bush margin). The other three commentators face even greater difficulties using their approaches. Mortimer Mittelpunkt would reduce Bush and Gore equally, by 2 each. The 999-to-666 ratio from the precinct totals leads Decimo Doyen to cutbacks of 2.4 for Bush and 1.6 for Gore, which Sally Sage would round to 2 and 2. Flummoxed and embarrassed upon finally grasping that Bush has only 1 vote to take away, these three stars rethink and toy, at least briefly, with the idea of backing the remedy advanced by the Gore side.

The disorder continues, with disputes all over Florida like the ones above (although they may be less discordant in precincts, unlike the three covered here, where the side with more converted undervotes also has a higher precinct total). The eventual outcome of the furor is left for the reader to imagine.

The "secondary snags" mentioned earlier refer to possible happenings that could only exacerbate matters further but are ignored here to avoid complexities. For instance, a ballot that has one presidential chad fully and one partially punched could tally as an overvote on one run but as a valid vote on the other (e.g., see Lund 2002, pp. 156-57). Also between the two runs, different ballots could change in opposite ways, such as some going from valid vote to undervote and others vice versa.

Evidence for the plausibility of two machine runs not identifying the same ballots as undervotes, the glitch that fuels the type of tumult that Scenario 2 illustrates, is ample. In Miami-Dade County, 10,750 undervotes were found the day after the election but 107 fewer turned up in a later recount (de Vise and Long 2000). Before the December 9 recount was stopped by the U.S. Supreme Court, it yielded 2409 undervotes in Marion County, which was 35 shy of the number tallied on November 8 (Barancik 2000), and it yielded 6 undervotes in a single precinct in Citrus County versus 8 that were thought to exist (Nohlgren and Pittman 2000). Pasco County counted 1710 undervoted ballots on December 9 versus 66 more than that on November 8 (Long and Silva 2000). For other mention about vote tabulations changing from one machine run to another, see (e.g.,) New York Times Co. (2001, pp. 44-45), Dershowitz (2001, p. 34), and Pleasants (2004, pp. 96-97). 
Two main media-sponsored studies reexamined the Florida ballots months after the election. Both of them looked only at rejected ballots, which were first pulled out from the other ballots without retallying of the latter, thus necessarily generating the very same identifiability problem that existed for the election itself. Both studies acknowledged this flaw, albeit somewhat opaquely. In the investigation done by The Miami Herald and others, Duval County produced 5106 undervote ballots for that study versus 4967 reported earlier, and only eight Florida counties provided the study a number of undervote ballots that agreed exactly with their earlier reporting (Merzer 2001, p. 178). The other review, conducted by National Opinion Research Center (NORC) for a media consortium, found discrepancies of similar import (see, e.g., NORC material in deHaven-Smith 2005, pp. 74-76). At the county level, 38 of Florida's 67 counties showed NORC a county total of fewer rejected ballots than reported earlier-1862 fewer altogether; 18 provided more than expected -426 more in total; and only 11 counties produced a number of rejected ballots that agreed precisely with the county total they found earlier. At the precinct level, the number of rejected ballots shown to NORC was in exact agreement with earlier reports in just 3877 out of 6151 Florida precincts, and was within 5 of what was expected from earlier reporting in 5583 precincts. In those precincts with a discrepancy of 1 to 5 (presumably $5583-3877=1706$ of them), the total shortage of rejected ballots in precincts with a deficiency was 1682, and the total excess in the precincts with extra uncounted ballots versus previous reports was 1368 .

The ferocity of the haggling over mere handfuls of votes in Scenario 2 is plausible only because the election in Florida was extremely close (and because whoever won Florida would become president). That closeness was obvious both early on and from the results of the two media studies. They concluded, generally (e.g., Viglucci 2001), that Bush apparently still would have barely won if the recount of undervotes had not been halted, but that Gore could have narrowly won if both undervotes and overvotes had been recounted statewide (an option that the Gore team never pursued).

As Scenario 2 illuminates, the basic problem in trying to recount a set of undervotes is that the set effectively does not exist-that is, it is nonidentifiable, irrecoverable, and unreconstructible. The set of undervotes (or, for that matter, overvotes) that existed in the earlier run for any precinct cannot properly be extracted from its entire set of ballots previously counted, because the second run or inspection may yield different rejected ballots from the first. Plainly, the only way to avoid this crucial trap and achieve the best accuracy possible would have been to do a rerun and recount of all six million Florida ballots while simultaneously pulling out ballots rejected as undervotes (or overvotes). Note that, although the U.S. Supreme Court ruling under Scenario 2 stipulates that any recount is to cover undervotes only, the same nonidentifiability issue as before would arise if the stipulation covered overvotes also (with the rejected ballots being isolated from the valid ones, and, again, no machine or other recount of the latter).

The county elections supervisor in Hillsborough County, Florida was well aware of the nonidentifiability quagmire. For ballots found as undervotes on the earlier run but not later, she recognized that the only way to get them tallied was to run all the ballots through the card readers for a new automated recount, but she said that remedy was unavailable unless a court asked for it. She apparently felt that the court was not aware that some ballots (those initially tallied as undervotes but later found to be valid votes) would improperly go uncounted without a complete rerun (Long and Silva 2000).

Given the large number of attorneys and judges who were involved in the Florida recount battle, one may wonder why the nonidentifiability flaw escaped proper recognition at the time. Actually, it appears that the Bush and Gore forces may both have been at least partly cognizant of it, if only belatedly. The Bush camp brought it up in briefs on December 9 and later (Whitman 2003, pp. 220-21, 230-31) by indicating that Miami-Dade County found 120 precincts with fewer undervotes and 34 with more undervotes in a later machine run than in an earlier one, and by claiming that votes could be double counted if a later run found more undervotes. A December 13 Gore brief that was written but never filed (see Tapper 2001b, pp. 459,497-500) proposed that, if there had to be a statewide recount covering both overvotes and undervotes, it could properly be accomplished through a fresh machine tally of all ballots registering one and only one vote for president done together with a segregation of 
all other ballots (ballots that would then be examined manually). That proposal seems to acknowledge implicitly that there would be an identifiability problem without the new machine tally of those ballots that the machine counted as votes.

The identifiability issue in the 2000 election in Florida has evidently received little notice in ensuing years. Exceptions, though, include Potthoff (2005) along with a response by Finkelstein and Levin (2005). These pieces focus on problems arising from the discrepant numbers of undervotes, and also overvotes, that can be produced in two separate machine runs of the ballots.

One might ask whether the U.S. Supreme Court majority that stopped the 2000 recount could have largely deflected the barrage of criticism that was heaped upon it by somehow playing the nonidentifiability card. Instead of ending the recount altogether, could it have achieved (in view of time constraints) the same practical effect, with reduced controversy, by ruling that a recount could be done but would have to involve all six million or so ballots in such a way as to prevent nonidentifiability of the limited sets of ballots to be examined manually?

One may speculate as to what might have transpired if, immediately after November 7, the Gore forces had consulted a statistician specializing in sampling. (They did, in fact, entertain two unfruitful, and questionable, efforts to apply statistical methodology to advance their cause, through statistical adjustment of vote totals to compensate for irregularities regarding the butterfly ballot in Palm Beach County and absentee ballots in Seminole County; see, respectively, Dershowitz 2001, p. 26; and Political Staff of The Washington Post 2001, p. 185. In addition, a statistician for the Gore side was a witness in a key hearing on December 2 but had a bit of a misadventure, as described, e.g., by Toobin 2001, pp. 218-20.) Florida election law would have allowed the Democrats to select, in each and any county, a group of three precincts and request a manual recount of those three (Dershowitz 2001, p. 212; Tapper 2001b, p. 91; Toobin 2001, p. 84). Thus, $201(=3 \times 67)$ Florida precincts could have been drawn based on proper statistical sampling principles (not by cherry-picking precincts likely to produce results favorable to Gore), after which the recounting of those precincts would enable one to obtain a valid statewide point estimate and confidence interval for the net gain or loss of votes that Gore would realize from a statewide recount. Such a sampling plan, the only choice both statistically sound and legally possible, would be highly inefficient (because of its heavy overrepresentation of counties with smaller versus larger population). But its very inefficiency would produce a wide confidence interval, and thereby aid Gore by raising the prospects of creating enough doubt about Bush's win to justify a call for a full statewide retally. Any barriers or legal challenges to the 67 county recounts would, of course, have to be overcome. Posner (2001, pp. 193-97) cites several factors that (ex ante) would justify the Gore camp's shying away from a statewide recount (including one covering overvotes as well as undervotes), but also acknowledges the contrary views of Kalt (2001), who thinks Gore had ample reason early on to pursue the statewide route and made a serious mistake by not doing so. Tapper (2001a) is likewise highly critical of the Gore camp for eschewing the statewide option. See also (New York Times Co. (2001, pp. 331-34), “Gore's Critical Mistake: Failure to Ask for a Statewide Recount"). As noted earlier, the indications from the media studies were that Gore could have won a statewide recount that included the reexamination of overvotes. Any recount would have had to contend with the nonidentifiability issue that bedevils Scenario 2.

It was indicated at the outset that, under Scenario 2, anything that happened before December 9 was assumed to be unchanged. Many familiar factors concerning the 2000 Florida conflict, most of which affected Gore adversely, arose prior to December 9. They include the butterfly ballot in Palm Beach County; other faulty ballot designs elsewhere, as in Duval County; the special treatment of absentee ballots in Martin and Seminole Counties; the handling of late-arriving absentee military ballots from overseas, and Joseph Lieberman's related comments; charges of disenfranchisement of black voters, stemming especially from voter purge lists; network projections, before Panhandle polls closed, of a Gore win in Florida, possibly causing reduced Panhandle turnout; the part played by Katherine Harris; the contentious November 22 demonstration in Miami by Bush supporters; the effects of the case of Elian Gonzales; and votes for Nader. All of these are covered variously in the references cited 
heretofore. Additional works that are relevant, dealing mainly with the effects of faulty ballot design, overvotes, and the role of Nader, include Agresti and Presnell (2002), Herron and Sekhon (2003), Mebane (2004), Herron and Lewis (2007), and references therein.

Would straight plurality voting, without an Electoral College, have avoided the ills of the 2000 election? Under the condition that the altered electoral rules would not cause voter behavior to change, a clear winner-Gore-would have quickly emerged: The Gore-minus-Bush vote difference in the entire United States, though small (at 543,895 , or $0.52 \%$ of the total vote), was not minuscule as it was in the pivotal state of Florida. In addition, as it happens, evidently Gore was the Condorcet candidate nationwide, able to beat not only Nader (head-to-head), but also Bush because the Nader voters unsurprisingly leaned far more toward Gore than Bush (see Abramson et al. 2002, pp. 126-28, p. 294, note 12). Thus, if one accepts the desirability of the Condorcet candidate winning the election, then pure plurality voting in 2000 would have produced the "right" outcome (by that standard).

More needs to be considered, though. As Dasgupta and Maskin (2004, p. 94) say while discussing the 2000 U.S. presidential election in an article that espouses Condorcet voting systems, "There have been many complaints about the electoral college, but even if it were replaced by popular vote, serious problems would remain." They highlight the point that plurality voting (and, incidentally, also the Borda count) may fail to elect the Condorcet candidate.

Merely jettisoning the Electoral College would not save voters whose first choice is a minor candidate (such as Nader) from the troublesome dilemma-inevitable under plurality voting-of having to choose between voting for their favorite or for someone who could win. But that is certainly not the only problem. Suppose now that 300,000 of the nationwide voters for Gore in 2000 had voted instead for Bush. Then Bush would have narrowly been the plurality winner. Suppose also that Gore remained the Condorcet candidate, as would seem likely because Nader voters heavily favored Gore over Bush and constituted $73 \%$ of those who voted for neither Bush nor Gore. The plurality winner, Bush, would accordingly be the "wrong" winner.

Much has been written about the 36-day aftermath of the 2000 election. Unique features of our work here include (i) vividly pointing out, per Scenario 2, the inevitable disruption that would have occurred had the recount of the (unidentifiable) undercount ballots not been halted on December 9; and (ii) calling attention to a statistical sampling option, overlooked by the Gore strategists, that could have changed their fortunes.

\section{Scenario 3: 2024}

The National Popular Vote Interstate Compact (hereafter NPVIC) would perhaps be dubbed more accurately, or at least with greater exactitude, if the word "Popular" were changed to "Plurality." The book Every Vote Equal (Koza et al. 2013; hereafter EVE) covers the NPVIC in great detail. It considers arguments con (though it does not mention Miller 2012, Section 10) as well as pro, and includes an extensive bibliography. EVE takes a strong stand in criticizing the Electoral College, but certainly is not unique in that regard, as noted earlier.

The authority for the NPVIC stems from Article II, Section 1, paragraph 2 of the U.S. Constitution, which indicates that the manner in which a state appoints its electors to the Electoral College is left to each state to decide. Thus, any state (the District of Columbia is treated the same as a state) may choose to join the NPVIC and determine its electors in accord with the terms of the compact, which requires it to award its electoral votes to the nationwide plurality winner if the electoral votes of the member states total more than 269.

Under Scenario 3, enough states to satisfy this condition have become members of the NPVIC not long after the start of 2024. (No states withdraw, although even in a presidential year they are allowed to do so if before July 20.) It can be argued whether or not the NPVIC has to receive Congressional consent based on Article I, Section 10, paragraph 3 of the U.S. Constitution (see EVE, Sections 5.12, 9.11.3, and 9.16.5), but, to play it safe, backers of NPVIC ask for, and quickly receive, such consent, in March 2024. No successful court challenges to the NPVIC have come about at this point. 
Scenario 3 continues in the spring of 2024 with the formation of the Anti-NPV Demolition Brigade (hereafter ANPVDB), a diverse assortment of political junkies, wanderers, retirees, social-choice and voting-system theorists, mathematicians, psephologists, travel buffs drawn by tourist attractions, anti-establishment zealots, and mischief makers (or persons who are mixtures of some of these), united by a common skepticism of NPVIC. Some persons in the ANPVDB oppose the NPVIC out of a belief that it would hurt small states. Others have a different reason for being against it. Some simply want to keep the Electoral College as it is. Some do see faults in the Electoral College but have a general distaste for plurality voting, which the NPVIC enshrines but which they consider to be just about the worst voting system possible. Some are proponents (for single-winner elections) of specific alternatives to plurality voting, including approval voting (Brams and Fishburn 2007), Condorcet systems, the Borda count, and the alternative-vote method (also known as the single-winner version of the Hare system, or in certain circles as "instant runoff voting" or "ranked choice voting"). Some are motivated by a desire to open up a wide-ranging national debate about plurality voting and disabuse the American public of misconceptions that plurality voting is the only voting system that exists.

The target of the ANPVDB consists of four small-population states, each given only three electoral votes by the 2020 (as well as 2010) decennial census. None of the four belongs to the NVPIC. All four states are holding legislative sessions in 2024 (although sessions may be less extensive in even-numbered than in odd-numbered years).

The plan of the ANPVDB is to persuade these four states, first, that NVPIC would slash their influence (because their high ratio of electoral votes to population would be negated with the Electoral College effectively dismantled), and second, that they can undermine NVPIC by invoking Article II, Section 1, paragraph 2 of the U.S. Constitution (the same provision that NVPIC itself relies upon) to replace their plurality voting with another voting system for deciding which candidate gets their electoral votes. Not everyone within ANPVDB subscribes fully to the argument that NVPIC weakens states with low populations (in fact, note EVE, Section 9.4). But, without that argument, the four states would be far less inclined to discard plurality voting and try something different, a prime objective of many in the ANPVDB.

Tossing out plurality voting in a single state, rather than four, would be sufficient to throw sand into the gears of the NVPIC. That is because, if even one state uses a voting system other than plurality voting for choosing the candidate who wins its electoral votes, then the NVPIC runs into trouble: It is undefined because the "votes" it is supposed to tally are undefined. But the ANPVDB chooses to pursue all four states not only for a margin of safety, but also to attract more attention and to enhance the support for its causes.

After a kickoff meeting in Glacier National Park, the ANPVDB proceeds southward and converges upon Helena. Heeding the warning from the ANPVDB concerning adverse impact of the NPVIC on their state, the Montana legislature and governor agree to supplant their time-honored plurality voting. Influenced by the use of the Borda count in the ranking of sports teams, they choose the Borda count as their new system for presidential voting, despite its vulnerability to manipulation.

The ANPVDB moves eastward to Bismarck, stopping briefly along the way at Theodore Roosevelt National Park. The office-holders in North Dakota, wary of losing some clout if the NPVIC is not obstructed, change their basis for presidential voting from plurality to Hare (alternative vote).

Now the ANPVDB travels south to Pierre and advances its usual arguments. South Dakota officials are convinced. The state adopts approval voting in place of plurality voting to handle its presidential race.

The ANPVDB heads westward to the tourist spots in the Black Hills, and then south to Cheyenne to counsel again against the NPVIC. For its presidential vote, Wyoming shifts from plurality voting to a Condorcet system. In the unlikely event that the ballots show no Condorcet winner, the decision as to who receives Wyoming's three electoral votes is to devolve upon the state legislature.

Finally, the ANPVDB winds up its activities by going to Yellowstone and Grand Teton National Parks, where it celebrates its achievements. The use of four different alternatives to plurality voting in the four states that ANVPDB visited not only poses added challenges for NPVIC defenders but 
also highlights for the American public the existence of varied avenues for displacing plurality voting. Even before the 2024 election, it seems apparent that the maneuvers of the ANPVDB have thrown a monkey wrench into the NPVIC.

EVE, in Chapter 9, discusses 131 objections (or "myths") pertaining to the NPVIC, and largely gives effective, or at least reasonable, answers to these. But the one objection that is exposed by Scenario 3 is not recognized at all, and is arguably of far greater potential gravity than any of the 131. In addition, of course, EVE does not deal with the controversial issue of whether plurality voting is desirable in the first place (although even an ardent supporter of plurality voting should find Scenario 3 worrisome).

Oddly, though, EVE does mention one system other than plurality voting-namely, Hare, or instant-runoff voting - in two places. The authors note that voters considered an initiative (it was defeated) "for instant run-off voting for presidential electors and other offices in Alaska in 2002" (EVE, p. 328), but give no indication as to how the NPVIC could handle such a system with its ranked ballots. Then a lengthy discussion (EVE, p. 491, footnote 239) hazily broaches the possibility of actualizing instant-runoff voting "at some time in the future" but, again, is oblivious to the necessity (or impossibility?) of extending or interpreting the provisions governing the NPVIC so that it can deal with instant-runoff voting. EVE makes no mention at all of alternatives such as approval voting, Condorcet systems, or the Borda count, or how the NPVIC might treat them.

Critics have claimed that the NPVIC could be derailed by a single state if, by resorting (of course) to Article II, Section 1, paragraph 2 of the U.S. Constitution, it were to either change its presidential ballot so that its voters would have to vote for electors individually, or else specify that its legislature would decide how to award its electoral votes; but such moves, though Constitutional, are largely forestalled by language in the NPVIC (EVE, Section 9.24). With either move, a state would be left out of the nationwide count that the NPVIC uses to determine the national plurality winner. In the text of the NPVIC (EVE, Section 6.2), Article III-1 indicates that this count is to be based on "the number of votes for each presidential slate" in each state that has a "statewide popular election," a term defined by Article V-8 to be "a general election in which votes are cast for presidential slates by individual voters and counted on a statewide basis."

The use of the word "slate," which refers to a presidential and vice-presidential candidate pair, means that the NPVIC would count none of the votes in a state that might try to thwart the NPVIC by having its voters vote for electors individually (a move that would prevent a unique vote tally for the NPVIC, because different electors would almost surely receive differing numbers of votes). The restriction to a "statewide popular election" means that if, in an effort to cripple the NPVIC, a state shifted the decision of how to cast its electoral votes from its voters to its legislature, that move would likewise cause it to be left out. Thus, in the case of either move the NPVIC would still be operative, though the aberrant state would lose its voice. It is hardly likely, though, that either move would ever occur in the first place, because either one would be so far out of the mainstream as to generate widespread backlash from the citizenry of the state.

The two moves just discussed, though, are somewhat akin to those in the four states above. But the latter moves are different in a critical way: They do have the ability to disrupt the NPVIC and render it inoperative. First, as required, the ballots in the four states still show presidential slates, not individual electors. Second, if a state bases its presidential voting on the Borda count, instant-runoff voting, approval voting, or a Condorcet system, one can hardly argue that such an election fails to satisfy the NPVIC definition of a "statewide popular election" (quoted above). If nothing else, the mention of instant-runoff voting in two places in EVE, noted earlier, is implicit acknowledgment of an intent for NPVIC to accommodate state systems other than plurality voting (though how it would do so is left in limbo).

Might a monstrously twisted interpretation of the "statewide popular election" definition somehow require a state to use plurality voting in order to avoid nullification of its presidential election results for purposes of the NPVIC tally? Such an evasion would not only override the language of the definition but would also be tantamount to a deification of plurality voting. 
The saga of Scenario 3 can now resume. As the presidential campaign starts to crystallize after the middle of 2024, Pat Peach and Robin Holly are the two leading candidates, with Peach in a wide lead over Holly. It thus appears that Peach will win easily, whether according to the usual Electoral College count or based on the NPVIC. NPVIC has still been impervious to court challenges, though they would have little immediate impact anyway in a landslide election. The minor presidential candidates consist mainly of Dana Cherry and Drew Beech.

Then, not long before the November 5 election, a sweeping bribery scandal engulfs Peach, who drops precipitously in the polls. Holly is now a heavy favorite. But the altered stability is not to last. Shortly come revelations that Holly is guilty of flagrant personal misbehavior. The election is now a tussle among all four candidates.

Election returns come in fast on November 5 and 6. The plurality winner is not in doubt in any state that uses plurality voting. With an assumption that the NPVIC is not in effect, the nationwide electoral-vote totals outside the four states without plurality voting are 133 for Peach, 132 for Beech, 131 for Holly, and 130 for Cherry (a total of $526=538-4 \times 3$ ). The nationwide plurality-vote totals from those same states are also close, with Beech in first place and ahead of Cherry by 100,000 votes, Cherry atop Peach by 100,000, and Peach leading Holly by 100,000.

The ballot counts for the four states without plurality voting appear in Table 5 for three of them and in Table 6 for the fourth (South Dakota). Undoubtedly, some aspects of these numbers are unrealistic. In particular, in Table 5 the exact equality of the three states' ballot percentages of candidate orderings could hardly happen. Moreover, this table shows only 4 candidate orderings, but another $20(=4 !-4)$ can occur on ballots with all 4 candidates ranked (plus many more on ballots with incomplete rankings ${ }^{2}$ ). Table 6 displays only 9 ballot markings for South Dakota, though there are 14 possible ways to cast approval votes for 1, 2, or 3 of the 4 candidates. But the artificiality of the ballot results with the small tables enables easier understanding yet sacrifices nothing regarding elucidation of the principles that are illustrated.

With NPVIC treated (at this point) as inoperative, the top part of each of Tables 6-9 shows, respectively, the calculations to find the approval-vote winner in South Dakota (Cherry); the Borda winner in Montana (Beech); the Hare winner in North Dakota (Holly); and the Condorcet winner in Wyoming (Cherry). Intriguingly, Tables 7-9 have three different winners even though their ballot percentages are identical. The electoral-vote totals for the entire U.S. are now $136(=130+6)$ for Cherry, $135(=132+3)$ for Beech, $134(=131+3)$ for Holly, and 133 for Peach, so that, per the 12th Amendment to the U.S. Constitution, the U.S. House will have to choose among Cherry, Beech, and Holly. Or so contend the ANPVDB and other NPVIC opponents.

But the NPVIC proponents do not surrender without a fight. To try to rescue their handiwork, they desperately engage in sundry mathematical gymnastics to obtain pseudo plurality votes that profess to be comparable to the results for each non-plurality system. Three of their devised methods, obviously discordant with one another, are covered in the bottom part of each of Tables 6-9. Further discords exist. Although not an occurrence in Tables 7-9, Methods M1, M2, ND1, ND2, and W2 can produce negative votes (a condition that some NPVIC defenders condone). Of the remaining seven methods, all but SD1 produce a (pseudo) plurality winner different from the actual winner in Tables 6-9. ${ }^{3}$

2 If rules allow a voter to rank only 1 or 2 candidates at the top, only 1 or 2 at the bottom, or just 1 at the top and 1 at the bottom, then the number of ways to do the ranking increases, respectively, by 16,16 , and 12 , giving a total of $16+16+12+20+4=68$ possible ways to mark the ballot.

3 Tables 6-9 show details of the methods. M3, ND3, and W3 all have the same percentages of final votes as each other, because all follow the same top-rank percentage distribution; SD3 happens to have these same percentages, but is based on only those ballots with a single approval vote and converts to the sum of 480 through multiplication. Also through multiplication, SD1 converts total approval votes to sum to 480. SD2 weights approval votes by the reciprocal of the number of approval votes on the ballot. M1 and M2 convert to the sum of 600 through subtraction after first (in effect) recalculating the Borda count with, respectively, points of $1 \frac{1}{2}, 1,1 / 2,0$ (point difference is $1 \frac{1}{2}-1 / 2=1$ between top-choice score and averaged bottom three scores on a ballot with a bullet vote) and $1,2 / 3,1 / 3,0$ (difference is $1-0=1$ between top and bottom). W1, which converts through multiplication, has values that are proportional to those on lines 5, 6, and 8 of Table 7 (not a coincidence). W2, ND1, and ND2 each convert their particular values through subtraction. 
Table 5. Ballot percentages and number of ballots by ballot ranking of Beech (B), Cherry (C), Holly (H), and Peach (P), for three states (2024 election, Scenario 3).

\begin{tabular}{ccrrr}
\hline & & \multicolumn{3}{c}{ Number of Ballots } \\
\hline $\begin{array}{c}\text { Ballot Ranking (1, } \\
\mathbf{2 , 3 , 4} \mathbf{;} \text { 1 = Highest) }\end{array}$ & $\begin{array}{c}\text { \% Of Ballots (Same } \\
\text { for All Three States) }\end{array}$ & Montana & North Dakota & Wyoming \\
\hline B, H, C, P & $15 \%$ & 90,000 & 60,000 & 54,000 \\
C, B, H, P & 20 & 120,000 & 80,000 & 72,000 \\
H, B, C, P & 30 & 180,000 & 120,000 & 108,000 \\
P, C, B, H & 35 & 210,000 & 140,000 & 126,000 \\
Total & $100 \%$ & 600,000 & 400,000 & 360,000 \\
\hline
\end{tabular}

Table 6. Details for approval votes for South Dakota (2024 election, Scenario 3).

\begin{tabular}{|c|c|c|c|c|c|c|c|}
\hline \multirow[b]{2}{*}{ Line } & \multirow[b]{2}{*}{$\begin{array}{l}\text { Ballots with } \\
\text { Approval Votes for }\end{array}$} & \multirow[b]{2}{*}{$\begin{array}{l}\text { Number of } \\
\text { Ballots (000) }\end{array}$} & \multicolumn{5}{|c|}{$\begin{array}{c}\text { Number of Approval Votes (Lines 1-10) or } \\
\text { Derived Values and Pseudo Plurality Votes (Rest of Table), } \\
\text { in Thousands, for }\end{array}$} \\
\hline & & & Beech (B) & Cherry (C) & Holly (H) & Peach (P) & Total \\
\hline 1 & B only & 45 & 45 & & & & 45 \\
\hline 2 & C only & 60 & & 60 & & & 60 \\
\hline 3 & H only & 90 & & & 90 & & 90 \\
\hline 4 & P only & 105 & & & & 105 & 105 \\
\hline 5 & $B$ and $C$ & 24 & 24 & 24 & & & 48 \\
\hline 6 & $\mathrm{~B}$ and $\mathrm{H}$ & 48 & 48 & & 48 & & 96 \\
\hline 7 & $\mathrm{C}$ and $\mathrm{P}$ & 48 & & 48 & & 48 & 96 \\
\hline 8 & $\mathrm{~B}, \mathrm{C}$, and $\mathrm{H}$ & 45 & 45 & 45 & 45 & & 135 \\
\hline 9 & $\mathrm{~B}, \mathrm{C}$, and $\mathrm{P}$ & 15 & 15 & 15 & & 15 & 45 \\
\hline \multirow[t]{2}{*}{10} & Total & 480 & 177 & $\begin{array}{r}192 \\
\text { (winner) }\end{array}$ & 183 & 168 & 720 \\
\hline & \multicolumn{2}{|c|}{$\begin{array}{l}\text { Methods purporting to salvage } \\
\text { NPVIC by producing pseudo } \\
\text { plurality votes }\end{array}$} & & & & & \\
\hline 11 & \multicolumn{2}{|c|}{ Sum of Lines 1-4 } & 45 & 60 & 90 & 105 & 300 \\
\hline 12 & \multicolumn{2}{|c|}{ Sum of Lines 5-7 } & 72 & 72 & 48 & 48 & 240 \\
\hline 13 & \multicolumn{2}{|c|}{ Sum of Lines 8-9 } & 60 & 60 & 45 & 15 & 180 \\
\hline 14 & & 36 & 36 & 24 & 24 & 120 \\
\hline 15 & \multicolumn{2}{|c|}{$\begin{array}{l}1 / 2 \times \text { Line } 12 \\
1 / 3 \times \text { Line } 13\end{array}$} & 20 & 20 & 15 & 5 & 60 \\
\hline \multicolumn{3}{|c|}{ Method SD1: $(480 / 720) \times$ Line 10} & 118 & * 128 & 122 & 112 & 480 \\
\hline \multicolumn{3}{|c|}{ Method SD2: Sum of Lines 11, 14, and 15} & 101 & 116 & 129 & * 134 & 480 \\
\hline \multicolumn{3}{|c|}{ Method SD3: $(480 / 300) \times$ Line 11} & 72 & 96 & 144 & $* 168$ & 480 \\
\hline
\end{tabular}

*Winner (last three lines). 
Table 7. Details for Borda count for Montana (2024 election, Scenario 3).

\begin{tabular}{|c|c|c|c|c|c|c|c|}
\hline \multirow[b]{2}{*}{ Line } & \multirow[b]{2}{*}{ Ballot Ranking } & \multirow[b]{2}{*}{$\begin{array}{l}\text { Number of } \\
\text { Ballots (000) }\end{array}$} & \multicolumn{5}{|c|}{$\begin{array}{c}\text { Borda Points-3, 2, 1, } 0 \text { for Ranks 1, 2, 3, } 4 \text { (Lines 1-5) or } \\
\text { Derived Values and Pseudo Plurality Votes (Rest of Table), } \\
\text { in Thousands, for }\end{array}$} \\
\hline & & & Beech (B) & Cherry (C) & Holly (H) & Peach (P) & Total \\
\hline 1 & $\mathrm{~B}, \mathrm{H}, \mathrm{C}, \mathrm{P}$ & 90 & 270 & 90 & 180 & 0 & 540 \\
\hline 2 & $\mathrm{C}, \mathrm{B}, \mathrm{H}, \mathrm{P}$ & 120 & 240 & 360 & 120 & 0 & 720 \\
\hline 3 & $\mathrm{H}, \mathrm{B}, \mathrm{C}, \mathrm{P}$ & 180 & 360 & 180 & 540 & 0 & 1080 \\
\hline 4 & $\mathrm{P}, \mathrm{C}, \mathrm{B}, \mathrm{H}$ & 210 & 210 & 420 & 0 & 630 & 1260 \\
\hline 5 & Total & 600 & $\begin{array}{r}1080 \\
\text { (winner) }\end{array}$ & 1050 & 840 & 630 & 3600 \\
\hline \multicolumn{8}{|c|}{$\begin{array}{l}\text { Methods purporting to salvage } \\
\text { NPVIC by producing pseudo } \\
\text { plurality votes }\end{array}$} \\
\hline 6 & \multicolumn{2}{|c|}{$1 / 2 \times$ Line 5} & 540 & 525 & 420 & 315 & 1800 \\
\hline 7 & \multicolumn{2}{|c|}{$(1800-600) \div 4$} & 300 & 300 & 300 & 300 & 1200 \\
\hline 8 & \multicolumn{2}{|c|}{$1 / 3 \times$ Line 5} & 360 & 350 & 280 & 210 & 1200 \\
\hline 9 & \multicolumn{2}{|c|}{$(1200-600) \div 4$} & 150 & 150 & 150 & 150 & 600 \\
\hline \multicolumn{3}{|c|}{ Method M1: Line 6 - Line 7} & * 240 & 225 & 120 & 15 & 600 \\
\hline \multicolumn{3}{|c|}{ Method M2: Line 8 - Line 9} & * 210 & 200 & 130 & 60 & 600 \\
\hline \multicolumn{3}{|c|}{ Method M3: Matches top rank on ballot } & 90 & 120 & 180 & * 210 & 600 \\
\hline
\end{tabular}

* Winner (last three lines).

Table 8. Details for Hare system for North Dakota (2024 election, Scenario 3).

\begin{tabular}{|c|c|c|c|c|c|c|c|}
\hline \multirow[b]{2}{*}{ Line } & \multirow[b]{2}{*}{ Ballot Ranking } & \multirow[b]{2}{*}{$\begin{array}{l}\text { Number of } \\
\text { Ballots (000) }\end{array}$} & \multicolumn{5}{|c|}{$\begin{array}{c}\text { Total Votes for Hare Rounds (Lines 6-10) or } \\
\text { Derived Values and Pseudo Plurality Votes (Rest of Table), } \\
\text { in Thousands, for }\end{array}$} \\
\hline & & & Beech (B) & Cherry (C) & Holly (H) & Peach (P) & Total \\
\hline 1 & $\mathrm{~B}, \mathrm{H}, \mathrm{C}, \mathrm{P}$ & 60 & & & & & \\
\hline 2 & $\mathrm{C}, \mathrm{B}, \mathrm{H}, \mathrm{P}$ & 80 & & & & & \\
\hline 3 & $\mathrm{H}, \mathrm{B}, \mathrm{C}, \mathrm{P}$ & 120 & & & & & \\
\hline 4 & $\mathrm{P}, \mathrm{C}, \mathrm{B}, \mathrm{H}$ & 140 & & & & & \\
\hline 5 & Total & 400 & & & & & \\
\hline 6 & First round (fr & n Lines 1-4) & 60 & 80 & 120 & 140 & 400 \\
\hline 7 & Transfer vote & rom Beech & -60 & & +60 & & \\
\hline 8 & Second & ound & & 80 & 180 & 140 & 400 \\
\hline 9 & Transfer votes & rom Cherry & & -80 & +80 & & \\
\hline \multirow[t]{3}{*}{10} & Third & und & & & 260 & 140 & 400 \\
\hline & & & & & (winner) & & \\
\hline & \multicolumn{2}{|c|}{$\begin{array}{l}\text { Methods purporting to salvage } \\
\text { NPVIC by producing pseudo } \\
\text { plurality votes }\end{array}$} & & & & & \\
\hline 11 & \multicolumn{2}{|c|}{ Final value in lines $6,8,10$} & 60 & 80 & 260 & 140 & 540 \\
\hline 12 & \multicolumn{2}{|c|}{$(540-400) \div 4$} & 35 & 35 & 35 & 35 & 140 \\
\hline 13 & \multicolumn{2}{|c|}{ Final value in lines $6,8,10$} & 60 & 80 & 260 & 140 & \\
\hline 14 & \multicolumn{2}{|c|}{ Winner's votes in same round } & 120 & 180 & 260 & 260 & \\
\hline 15 & \multicolumn{2}{|c|}{ Line 14 - Line 13} & 60 & 100 & 0 & 120 & 280 \\
\hline 16 & \multicolumn{2}{|c|}{$(280+400) \div 4$} & 170 & 170 & 170 & 170 & 680 \\
\hline \multicolumn{3}{|c|}{ Method ND1: Line 11 - Line 12} & 25 & 45 & * 225 & 105 & 400 \\
\hline \multicolumn{3}{|c|}{ Method ND2: Line 16 - Line 15} & 110 & 70 & * 170 & 50 & 400 \\
\hline \multicolumn{3}{|c|}{ Method ND3: Same as Line 6 (top rank) } & 60 & 80 & 120 & * 140 & 400 \\
\hline
\end{tabular}

* Winner (last three lines). 
Table 9. Details for Condorcet voting for Wyoming (2024 election, Scenario 3).

\begin{tabular}{|c|c|c|c|c|c|c|c|}
\hline \multirow[b]{2}{*}{ Line } & \multirow[b]{2}{*}{ Ballot Ranking } & \multirow[b]{2}{*}{$\begin{array}{l}\text { Number of } \\
\text { Ballots (000) }\end{array}$} & \multicolumn{5}{|c|}{$\begin{array}{c}\text { Condorcet Votes or Indicators (Lines 6-13) or } \\
\text { Derived Values and Pseudo Plurality Votes (Rest of Table), in } \\
\text { Thousands, for }\end{array}$} \\
\hline & & & Beech (B) & Cherry (C) & Holly (H) & Peach (P) & Total \\
\hline 1 & $\mathrm{~B}, \mathrm{H}, \mathrm{C}, \mathrm{P}$ & 54 & & & & & \\
\hline 2 & $\mathrm{C}, \mathrm{B}, \mathrm{H}, \mathrm{P}$ & 72 & & & & & \\
\hline 3 & $\mathrm{H}, \mathrm{B}, \mathrm{C}, \mathrm{P}$ & 108 & & & & & \\
\hline 4 & $\mathrm{P}, \mathrm{C}, \mathrm{B}, \mathrm{H}$ & 126 & & & & & \\
\hline \multirow[t]{2}{*}{5} & Total & 360 & & & & & \\
\hline & \multicolumn{2}{|c|}{$\begin{array}{l}\text { Ballots (000) on which candidate } \\
\text { at head of column is ranked above }\end{array}$} & & & & & \\
\hline 6 & \multicolumn{2}{|c|}{ Beech } & - & 198 & 108 & 126 & \\
\hline 7 & \multicolumn{2}{|c|}{ Cherry } & 162 & - & 162 & 126 & \\
\hline 8 & \multicolumn{2}{|c|}{ Holly } & 252 & 198 & - & 126 & \\
\hline 9 & \multicolumn{2}{|c|}{ Peach } & 234 & 234 & 234 & - & \\
\hline \multicolumn{8}{|c|}{$\begin{array}{l}\text { Shows }(1,0) \text { if candidate at head } \\
\text { of column (does, does not) beat }\end{array}$} \\
\hline 10 & \multicolumn{2}{|c|}{ Beech } & - & 1 & 0 & 0 & \\
\hline 11 & \multicolumn{2}{|c|}{ Cherry } & 0 & - & 0 & 0 & \\
\hline 12 & \multicolumn{2}{|c|}{ Holly } & 1 & 1 & - & 0 & \\
\hline \multirow[t]{3}{*}{13} & \multirow{2}{*}{\multicolumn{2}{|c|}{ Peach }} & 1 & 1 & 1 & - & \\
\hline & & & & (winner: all 1's) & & & \\
\hline & \multicolumn{2}{|c|}{$\begin{array}{l}\text { Methods purporting to salvage } \\
\text { NPVIC by producing pseudo } \\
\text { plurality votes }\end{array}$} & & & & & \\
\hline 14 & \multirow{3}{*}{\multicolumn{2}{|c|}{$\begin{array}{l}\text { Sum of Lines } 6-9 \\
\text { Margin by which Cherry (winner) } \\
\text { beats candidate at head of column } \\
\qquad(180+360) \div 4\end{array}$}} & 648 & 630 & 504 & 378 & 2160 \\
\hline 15 & & & 36 & 0 & 36 & 108 & 180 \\
\hline 16 & & & 135 & 135 & 135 & 135 & 540 \\
\hline \multicolumn{3}{|c|}{ Method W1: $(360 / 2160) \times$ Line 14} & $* 108$ & 105 & 84 & 63 & 360 \\
\hline \multicolumn{3}{|c|}{ Method W2: Line 16 - Line 15} & 99 & * 135 & 99 & 27 & 360 \\
\hline \multicolumn{3}{|c|}{ Method W3: Matches top rank on ballot } & 54 & 72 & 108 & * 126 & 360 \\
\hline
\end{tabular}

* Winner (last three lines).

The four candidates (especially Peach, of course) are not happy with throwing the election into the U.S. House: Each would prefer an outright win, via the NPVIC together with pseudo plurality votes. The race for highest nationwide total of genuine plus pseudo plurality votes will be won by Beech using SD1, M1, ND2, and W1; by Cherry using SD2, M3, ND3, and W2; by Holly with SD3, M3, ND1, and W2; and by Peach using SD3, M3, ND3, and W3 (See Table 10). Thus, with NPVIC, any of the four can win with the right selection of pseudo plurality votes. All four present rationales supporting the selection most favorable to them. The ANPVDB and its allies argue that all four rationales are purely self-serving, that the concept of pseudo plurality votes is ludicrous in the first place, and that the absurdity of the situation calls for annulling the NPVIC. 
Table 10. Detailed calculations (with values from Tables 6-9) showing that any of the four candidates can win the nationwide total of pseudo plurality votes (four states) plus (ordinary) plurality votes (elsewhere) by using chosen methods for the former votes (2024 election, Scenario 3).

\begin{tabular}{|c|c|c|c|c|c|c|}
\hline \multirow{2}{*}{ Candidate } & \multirow{2}{*}{ Votes from } & \multirow{2}{*}{ Method } & \multicolumn{4}{|c|}{ Vote Margin, in Thousands, Over } \\
\hline & & & Beech & Cherry & Holly & Peach \\
\hline \multirow[t]{6}{*}{ Beech } & S. Dakota & SD1 & & $118-128=-10$ & $118-122=-4$ & $118-112=6$ \\
\hline & Montana & M1 & & $240-225=15$ & $240-120=120$ & $240-15=225$ \\
\hline & N. Dakota & ND2 & & $110-70=40$ & $110-170=-60$ & $110-50=60$ \\
\hline & Wyoming & W1 & & $108-105=3$ & $108-84=24$ & $108-63=45$ \\
\hline & Elsewhere & Plurality & & 100 & 300 & 200 \\
\hline & Total $^{\text {a }}$ & & & 148 & 380 & 536 \\
\hline \multirow[t]{6}{*}{ Cherry } & S. Dakota & SD2 & $116-101=15$ & & $116-129=-13$ & $116-134=-18$ \\
\hline & Montana & M3 & $120-90=30$ & & $120-180=-60$ & $120-210=-90$ \\
\hline & N. Dakota & ND3 & $80-60=20$ & & $80-120=-40$ & $80-140=-60$ \\
\hline & Wyoming & W2 & $135-99=36$ & & $135-99=36$ & $135-27=108$ \\
\hline & Elsewhere & Plurality & -100 & & 200 & 100 \\
\hline & Total $^{\text {a }}$ & & 1 & & 123 & 40 \\
\hline \multirow[t]{6}{*}{ Holly } & S. Dakota & SD3 & $144-72=72$ & $144-96=48$ & & $144-168=-24$ \\
\hline & Montana & M3 & $180-90=90$ & $180-120=60$ & & $180-210=-30$ \\
\hline & N. Dakota & ND1 & $225-25=200$ & $225-45=180$ & & $225-105=120$ \\
\hline & Wyoming & W2 & $99-99=0$ & $99-135=-36$ & & $99-27=72$ \\
\hline & Elsewhere & Plurality & -300 & -200 & & -100 \\
\hline & Total $^{\text {a }}$ & & 62 & 52 & & 38 \\
\hline \multirow[t]{6}{*}{ Peach } & S. Dakota & SD3 & $168-72=96$ & $168-96=72$ & $168-144=24$ & \\
\hline & Montana & M3 & $210-90=120$ & $210-120=90$ & $210-180=30$ & \\
\hline & N. Dakota & ND3 & $140-60=80$ & $140-80=60$ & $140-120=20$ & \\
\hline & Wyoming & W3 & $126-54=72$ & $126-72=54$ & $126-108=18$ & \\
\hline & Elsewhere & Plurality & -200 & -100 & 100 & \\
\hline & Total $^{\mathrm{a}}$ & & 168 & 176 & 192 & \\
\hline
\end{tabular}

a Because all three values on this line are greater than zero, the associated candidate is the nationwide winner using the indicated set of four methods for obtaining the pseudo plurality votes.

As with Scenario 2, it is necessary to stop the tale at some point and leave the rest for the reader to imagine. The U.S. Supreme Court will doubtless be involved, though.

As we noted, the action of any one state would suffice to cripple the NPVIC through a stratagem that is overlooked, and whose threat is therefore not challenged or refuted, in the 1059 pages of $E V E$. Though a single-state example could thus make this point, the four-state portrayal given by Scenario 3 is more engaging and comprehensive.

\section{2016}

Hillary Clinton won the popular (plurality) vote but lost the electoral vote against Donald Trump in the 2016 presidential election. We do not attempt here to delve into that election and its complexities, though it manifested obvious major issues regarding both the Electoral College and plurality voting. Although the former issues are more striking and have drawn far more attention than the latter, the flaws of plurality voting could still have had a key impact. Thus (e.g.), in states where Trump's plurality-vote victory margins were narrow, he might not have been the Condorcet candidate.

\section{Conclusions}

One common thread in our three presidential-election scenarios involves the simplistic dismissal of (or failure to recognize) adverse factors or other elements that are partly hiding: peculiar incentives for freakish strategic voting in Scenario 1; nonidentifiability of undervote ballots (plus possible use of statistical sampling), disregarded in Scenario 2; and, overlooked in Scenario 3, fateful vulnerability of NPVIC to a single state renouncing plurality voting. A second thread in all three scenarios is the display of shortcomings involving the Electoral College. Finally, the scenarios expose serious drawbacks of plurality voting. 
How do the flaws of plurality voting compare with those of the Electoral College? One could at least question whether nationwide plurality voting without the Electoral College would be less or more likely than the present system to elect a Condorcet candidate (see Arrington and Brenner 1980, though). Ideally, however, one might like to scrap both the Electoral College and plurality voting.

One possible replacement would be (nationwide) approval voting (with all states' ballots offering the same candidate list). Another would be a Condorcet system, with fallback to Borda (Black 1958, p. 66; Dasgupta and Maskin 2004), Hare (Green-Armytage et al. 2016), or approval votes (Nurmi 1987, p. 176; Potthoff 2013, 2014) if no Condorcet winner emerges. [Hare (by itself) enjoys widespread attention, but suffers assorted handicaps (e.g., Fishburn and Brams 1983; Potthoff 2013, sct. 11).] Because a Constitutional amendment appears necessary for suitable change, though, adoption of any replacement system would likely face many obstacles. Unfortunately, the attendant problems seem daunting.

There is no silver bullet. Deciding on an electoral system is a complex problem even without the complication of the Electoral College. At least at present, a Constitutional amendment regarding the Electoral College appears almost impossible, a condition to which NPVIC backers seem to be resigned. But the NPVIC is itself infeasible, as it can be vitiated by the actions of a single state, per Scenario 3. Moreover, even if the Electoral College were somehow circumvented (via the NPVIC) or abolished (through Constitutional amendment), and replaced by nationwide plurality voting, the resulting setup could be just as likely to elect a president who fails to be a Condorcet candidate.

Yet, even in the short term, certain remedies may be feasible. Other avenues to the effective improvement of the processes surrounding presidential elections are open, although any sort of action by state legislatures is probably not one of them. Some improvement could come about without legal changes. The concept of a Condorcet candidate, along with the fact that such a candidate is generally a centrist rather than an extremist, is virtually unknown to the general public. This state of ignorance could be radically altered through appeals to education leaders and media leaders. As a further step, a Condorcet candidate for president at any point in time (change can occur with time) could be identified through Condorcet polling (Potthoff 2011; Potthoff and Munger 2015). The matter cannot be pursued further here, but one can conceive that developments triggered by such identification through Condorcet polling (starting before the presidential primaries) could allow a Condorcet candidate to receive more recognition and have a better chance to be elected president, even without legal changes to the electoral system.

Funding: This research received no external funding.

Acknowledgments: The author thanks the two reviewers for their helpful comments.

Conflicts of Interest: The author declares no conflict of interest.

\section{References}

Abramson, Paul R., John H. Aldrich, Phil Paolino, and David W. Rohde. 1995. Third-party and independent candidates in American politics: Wallace, Anderson, and Perot. Political Science Quarterly 110: 349-67. [CrossRef]

Abramson, Paul R., John H. Aldrich, and David W. Rohde. 2002. Change and Continuity in the 2000 Elections. Washington, DC: CQ Press.

Agresti, Alan, and Brett Presnell. 2002. Misvotes, undervotes and overvotes: The 2000 presidential election in Florida. Statistical Science 17: 436-40. [CrossRef]

Anonymous. 1968. Wallace candidacy raises fears of electoral stalemate. Congressional Quarterly Weekly Report 19: 1811-23.

Anonymous. 2000. Florida's recount. Palm Beach Post, December 11, p. 14A.

Arrington, Theodore S., and Saul Brenner. 1980. The advantages of a plurality election of the President. Presidential Studies Quarterly 10: 476-82. 
Axelrod, Robert. 1972. Where the votes come from: An analysis of electoral coalitions, 1952-1968. American Political Science Review 66: 11-20. [CrossRef]

Baker, Russell. 1968. Our Next President: The Incredible Story of What Happened in the 1968 Elections. New York: Atheneum.

Barancik, Scott. 2000. There's not going to be enough time. St. Petersburg Times, December 10, p. 5A.

Best, Judith A. 1996. The Choice of the People? Debating the Electoral College. Lanham: Rowman \& Littlefield.

Black, Duncan. 1958. The Theory of Committees and Elections. Cambridge: Cambridge University Press.

Brams, Steven J., and Peter C. Fishburn. 2007. Approval Voting, 2nd ed. New York: Springer.

Converse, Philip E., Warren E. Miller, Jerrold G. Rusk, and Arthur C. Wolfe. 1969. Continuity and change in American politics: parties and issues in the 1968 election. American Political Science Review 63: 1083-105. [CrossRef]

Dasgupta, Partha, and Eric Maskin. 2004. The fairest vote of all. Scientific American 290: 92-97. [CrossRef]

de Vise, Daniel, and Phil Long. 2000. Lewis gives local boards discretion. Miami Herald, December 9, p. 22A.

deHaven-Smith, Lance, ed. 2005. The Battle for Florida: An Annotated Compendium of Materials from the 2000 Presidential Election. Gainesville: University Press of Florida.

Dershowitz, Alan M. 2001. Supreme Injustice: How the High Court Hijacked Election 2000. New York: Oxford University Press.

Dummett, Michael. 1997. Principles of Electoral Reform. Oxford: Oxford University Press.

Edwards, George C., III. 2011. Why the Electoral College Is Bad for America, 2nd ed. New Haven: Yale University Press. Finkelstein, Michael O., and Bruce Levin. 2005. The editors reply. Chance 18: 4.

Fishburn, Peter C., and Steven J. Brams. 1983. Paradoxes of preferential voting. Mathematics Magazine 56: 207-14. [CrossRef]

Gallup, Inc. 2015. Election Polls—Vote by Groups, 1968-1972. Available online: http://www.gallup.com/poll/9457/ election-polls-vote-groups-19681972.aspx (accessed on 23 April 2018).

Gehrlein, William V. 2006. Condorcet's Paradox. Berlin: Springer.

Glennon, Michael J. 1992. When No Majority Rules: The Electoral College and Presidential Succession. Washington, DC: Congressional Quarterly.

Green-Armytage, James, T. Nicolaus Tideman, and Rafael Cosman. 2016. Statistical evaluation of voting rules. Social Choice and Welfare 46: 183-212. [CrossRef]

Hardaway, Robert M. 1994. The Electoral College and the Constitution: The Case for Preserving Federalism. Westport: Praeger.

Herron, Michael C., and Jeffrey B. Lewis. 2007. Did Ralph Nader spoil Al Gore's presidential bid? A ballot-level study of Green and Reform Party voters in the 2000 presidential election. Quarterly Journal of Political Science 2: 205-26. [CrossRef]

Herron, Michael C., and Jasjeet S. Sekhon. 2003. Overvoting and representation: An examination of overvoted presidential ballots in Broward and Miami-Dade Counties. Electoral Studies 22: 21-47. [CrossRef]

Hillygus, D. Sunshine, and Sarah A. Treul. 2014. Assessing strategic voting in the 2008 US presidential primaries: The role of electoral context, institutional rules, and negative votes. Public Choice 161: 517-36. [CrossRef]

Kalt, Brian C. 2001. The endless recount: Some thoughts on optimal recount strategy and Al Gore's plan in the 2000 Florida presidential race. Paper presented at the 2001 Annual Meetings of the Public Choice Society and Economic Science Association, San Antonio, TX, USA, March 10.

Kaplan, David A. 2001. The Accidental President: How 413 Lawyers, 9 Supreme Court Justices, and 5,963,110 (Give or Take a Few) Floridians Landed George W. Bush in the White House. New York: William Morrow.

Kiewiet, D. Roderick. 1979. Approval voting: The case of the 1968 election. Polity 12: 170-81. [CrossRef] 
Koza, John R., Barry F. Fadem, Mark Grueskin, Michael S. Mandell, Robert Richie, and Joseph F. Zimmerman. 2013. Every Vote Equal: A State-Based Plan for Electing the President by National Popular Vote, 4th ed. Los Altos: National Popular Vote Press, Available online: http://www.every-vote-equal.com/ (accessed on 23 March 2019).

Long, Phil, and Mark Silva. 2000. Accurate recount might have been tough. Miami Herald, December 13, p. 32A. Longley, Lawrence D., and Neal R. Peirce. 1999. The Electoral College Primer 2000. New Haven: Yale University Press. Lund, Nelson. 2002. The unbearable rightness of Bush v. Gore. In The Longest Night: Polemics and Perspectives on Election 2000. Edited by Arthur J. Jacobson and Michel Rosenfeld. Berkeley: University of California Press, pp. 144-88.

Markham, Sherwin. 1970. The Election. New York: Random House.

Mebane, Walter R., Jr. 2004. The wrong man is president! Overvotes in the 2000 presidential election in Florida. Perspectives on Politics 2: 525-35. [CrossRef]

Merrill, Samuel, III. 1988. Making Multicandidate Elections More Democratic. Princeton: Princeton University Press.

Merzer, Martin. 2001. The Miami Herald Report: Democracy Held Hostage. New York: St. Martin's Press.

Miller, Nicholas R. 2012. Why the Electoral College is good for political science (and public choice). Public Choice 150: 1-25. [CrossRef]

New York Times Co. 2001. 36 Days: The Complete Chronicle of the 2000 Presidential Election Crisis. New York: Times Books.

Nohlgren, Stephen, and Craig Pittman. 2000. Short but chaotic day for counts. St. Petersburg Times, December 10, pp. $1 \mathrm{~A}, 4 \mathrm{~A}$.

Nurmi, Hannu. 1987. Comparing Voting Systems. Dordrecht: Reidel.

Peirce, Neal R., and Lawrence D. Longley. 1981. The People's President: The Electoral College in American History and the Direct Vote Alternative, rev. ed. New Haven: Yale University Press.

Pleasants, Julian M. 2004. Hanging Chads: The Inside Story of the 2000 Presidential Recount in Florida. New York: Palgrave Macmillan.

Political Staff of The Washington Post. 2001. Deadlock: The Inside Story of America's Closest Election. New York: Public Affairs.

Posner, Richard A. 2001. Breaking the Deadlock: The 2000 Election, the Constitution, and the Courts. Princeton: Princeton University Press.

Potthoff, Richard F. 2005. Letter to the editor: A neglected issue in Florida in 2000? Chance 18: 3-4. [CrossRef]

Potthoff, Richard F. 2011. Condorcet polling. Public Choice 148: 67-86. [CrossRef]

Potthoff, Richard F. 2013. Simple manipulation-resistant voting systems designed to elect Condorcet candidates and suitable for large-scale public elections. Social Choice and Welfare 40: 101-22. [CrossRef]

Potthoff, Richard F. 2014. Condorcet completion methods that inhibit manipulation through exploiting knowledge of electorate preferences. Games 5: 204-33. [CrossRef]

Potthoff, Richard F., and Michael C. Munger. 2015. Condorcet polling can yield serendipitous clues about voter views. Public Choice 165: 1-12. [CrossRef]

Poundstone, William. 2008. Gaming the Vote. New York: Hill and Wang.

Regenwetter, Michel, Bernard Grofman, Anthony A. J. Marley, and Ilia M. Tsetlin. 2006. Behavioral Social Choice: Probabilistic Models, Statistical Inference, and Applications. New York: Cambridge University Press.

Ross, Tara. 2012. Enlightened Democracy: The Case for the Electoral College, 2nd ed. Dallas: Colonial Press.

Saari, Donald G. 1995. Basic Geometry of Voting. Berlin: Springer.

Sabato, Larry J. 2007. A More Perfect Constitution: 23 Proposals to Revitalize Our Constitution and Make America a Fairer Country. New York: Walker \& Co.

Tapper, Jake. 2001a. And the Winner Was? Available online: http://www.salon.com/2001/04/04/bush_wins/ (accessed on 23 March 2019).

Tapper, Jake. 2001b. Down and Dirty: The Plot to Steal the Presidency. Boston: Little, Brown.

Tideman, Nicolaus. 2006. Collective Decisions and Voting: The Potential for Public Choice. Aldershot: Ashgate Publishing.

Toobin, Jeffrey. 2001. Too Close to Call: The Thirty-Six-Day Battle to Decide the 2000 Election. New York: Random House.

U.S. Bureau of the Census. 1969. Voting and registration in the election of November 1968. In Current Population Reports; Series P-20, No. 192; Washington, DC: U.S. Government Printing Office. 
U.S. Bureau of the Census. 1973. Census of Population: 1970, Characteristics of the Population; Table 20 in Parts 11, Florida; 35, North Carolina; 42, South Carolina; and 44, Tennessee. Washington, DC: U.S. Government Printing Office, vol. 1.

Venetoulis, Theodore G. 1968. The House Shall Choose. Margate: Elias Press.

Viglucci, Andres. 2001. New study shows Bush-Gore still a tough call. Miami Herald, November 12, p. 9A.

Whitman, Mark, ed. 2003. Florida 2000: A Sourcebook on the Contested Presidential Election. Boulder: Lynne Rienner.

(c)

(C) 2019 by the author. Licensee MDPI, Basel, Switzerland. This article is an open access article distributed under the terms and conditions of the Creative Commons Attribution (CC BY) license (http://creativecommons.org/licenses/by/4.0/). 